\title{
KOMUNIKASI ISLAM DAN PERUBAHAN SOSIAL
}

\author{
M. Zakaria Al Anshori \\ Unismu Makassar \\ e-mail: zakaria_alanshari@yahoo.co.id
}

\begin{abstract}
Social change is a social process experienced by members of society and all elements of culture and social systems, where all levels of people's lives are voluntary or influenced by external elements by abandoning the patterns of life, culture, and social systems long after adjust or use new patterns of life, culture, and social systems. With the existence of social change, of course, Islamic communication has challenges that must be passed and decomposed holistically, by finding and finding alternative solutions for the effectiveness and accuracy of contemporary Islamic communication. Among the concrete problems in the behaviour of social change, for example, modern society today abandons traditional values, has a hedonistic lifestyle and acts spree and so on. Therefore, Islamic communication must lead to handling real problems. This means that Islamic communication activities are efforts to solve or solve the problems of the life of the people and society in the socio-cultural, economic and political fields within the framework of modern society. The form of Islamic communication can be done formally in the activities of individuals in academia, social education institutions and da'wah institutions, and can also be done non-formally by individuals in the social life of the community.
\end{abstract}

\section{Key Words:}

Islamic Communication, Society, Social Change 


\begin{abstract}
Abstrak
Perubahan sosial merupakan proses sosial yang dialami oleh anggota masyarakat serta semua unsur-unsur budaya dan sistem-sistem sosial, dimana semua tingkat kehidupan masyarakat secara sukarela atau dipengaruhi oleh unsur-unsur eksternal dengan meninggalkan pola-pola kehidupan, budaya, dan sistem sosial lama kemudian menyesuaikan diri atau menggunakan pola-pola kehidupan, budaya, dan sistem sosial yang baru. Dengan adanya perubahan sosial tentunya komunikasi Islam memiliki tantangan yang harus dilalui dan diurai secara holistik, dengan mencari dan menemukan alternatif solutif bagi efektivitas dan ketepatan komunikasi Islam kontemporer. Di antara permasalahan konkrit pada perilaku perubahan sosial, misalnya Masyarakat modern saat ini lebih banyak meninggalkan nilai-nilai tradisional, adanya gaya hidup hedonisme dan berfoya,foya dan lain sebagainya. Oleh karena itu, komunikasi Islam harus mengarah pada penanganan masalah riil. Artinya bahwa kegiatan komunikasi Islam merupakan usaha pemecahan atau penyelesaian masalah kehidupan umat dan masyarakat di bidang sosial-budaya, ekonomi dan politik dalam kerangka masyarakat modern. Adapun bentuk komunikasi Islam yang dapat dilakukan bisa secara formal dalam kegiatan individu di lingkungan akademisi, lembaga pendidikan sosial maupun lembaga dakwah, dan bisa juga secara non formal yang dilakukan oleh individu dalam kehidupan sosial masyarakat.
\end{abstract}

\title{
Kata Kunci:
}

Komunikasi Islam, Masyarakat, Perubahan Sosial 


\section{A. Pendahuluan}

Industrialisasi dan modernisasi merupakan ancaman terhadap realitas keagamaan. ${ }^{114}$ Ancaman ini tidak hanya tertuju pada ekspresi keagamaan bagi penganut agama Islam saja, tetapi bagi penganut agama-agama lain termasuk agama kristen katolik dan protestan juga akan mengalami hal yang serupa.

Modernisasi adalah suatu proses transformasi dan suatu perubahan ke arah yang lebih maju di berbagai aspek dalam kehidupan masyarakat. Secara sederhana, dapat dikatakan bahwa modernisasi adalah proses perubahan dan caracara tradisional ke cara-cara baru yang lebih maju dalam rangka untuk peningkatan kualitas hidup masyarakat, dan sebagai bentuk perubahan sosial, modernisasi merupakan bentuk perubahan sosial yang terarah dan terencana. Perencanaan sosial (social planning) dewasa ini menjadi ciri umum bagi masyarakat atau negara yang sedang mengalami perkembangan.

Di Indonesia, bentuk-bentuk modernisasi banyak kita jumpai di berbagai aspek kehidupan masyarakatnya, baik dari segi pertanian, industri, perdagangan, maupun sosial budayanya. Salah satu bentuk modernisasi di bidang pertanian adalah dengan adanya teknik-teknik pengolahan lahan yang baru dengan menggunakan mesin-mesin, pupuk dan obat-obatan, irigasi teknis, varietas-varietas unggulan baru, pemanenan serta penanganannya dengan penggunaan mesin dan teknologi modern. Semua itu merupakan hasil dari adanya modernisasi.

\footnotetext{
${ }^{114}$ Roland Robertson, ed., Sociology of Religion, Edisi terjemahan. Agama dalam Ánalisa dan Interpretasi Sosiologi (Cet. I; Jakarta: Rajawali Pers, 1988), 168
} 
Berbagai bidang tersebut dapat berkembang melalui serangkaian proses yang panjang sehingga mencapai pola-pola perilaku baru yang berwujud pada kehidupan masyarakat modern. Sayangnya, penggunaan istilah modernisasi banyak disalahartikan sehingga sisi moralnya terlupakan.

Pendidikan keagamaan dalam upaya penanaman iman dalam masyarakat modern dapat dilakukan dengan berbagai macam cara, diantaranya adalah dengan kegiatan komunikasi Islam, dimana kegiatan komunikasi Islam merupakan tugas utama para Nabi dan Rasul, mengajak manusia untuk beriman dan menyembah hanya kepada Allah swt., menyeru kepada kebaikan dan melarang untuk berbuat kemunkaran. ${ }^{115}$

Kegiatan komunikasi Islam Nabi Muhammad Saw., diperhitungkan kurang lebih selama 23 tahun lamanya beliau melakukan kegiatan komunikasi Islam dengan banyak metode dan teknik. ${ }^{116} \mathrm{Di}$ era modern sekarang ini, kegiatan komunikasi Islam konvensional (lisan, melalui mimbar) dirasa kurang cukup, komunikasi Islam selalu dikembangkan dan dikondisikan dengan memanfaatkan penggunaan teknologi informasi (seperti; cetak, elektronik, dan internet). Ajaran Islam semestinya dikomunikasikan dengan strategi yang tepat karena esensi komunikasi Islam adalah memberikan informasi, menyeru dan mengajak manusia kepada jalan Tuhannya untuk taat dan patuh pada ajarannya, serta kegiatan penghambaan yang didasari oleh sikap sabar dan ikhlas, sehingga untuk mendukung efektifitasnya diperlukan

\footnotetext{
${ }^{115}$ Philip K. Hitti, History of The Arabs, from the earliest times to the Present (Cet. X; London: The Macmillan Press Ltd, 1974), 113

116 Philip K. Hitti, History of The Arabs, Rujukcm IflthIEJC dan paling Otoriíaiftentang Sejarahn Peradaban Islam (Cet. II; Jakarta: PT Serambi Ilmu Semesta, 2006), 139
} 
pula pengetahuan mendalam tentang pokok-pokok landasan tentang komunikasi Islam, sebagaimana diisyaratkan didalam Alquran Q.S. al-Nahl/16:125

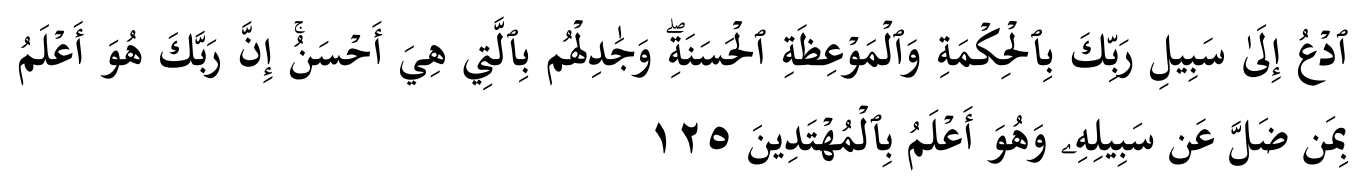

Terjemahnya:

"Serulah (manusia) kepada jalan Tuhan-mu dengan hikmah dan pelajaran yang baik dan bantahlah mereka dengan cara yang baik. Sesungguhnya Tuhanmu Dialah yang lebih mengetahui tentang siapa yang tersesat dari jalan-Nya dan Dialah yang lebih mengetahui orangorang yang mendapat petunjuk". ${ }^{117}$

Bila mengacu pada ayat tersebut maka komunikasi Islam adalah bagian integral dan umat Islam yang seyogyanya diaplikasikan dalam kehidupan sehari-hari oleh setiap individu muslim. Rasulullah Saw sendiri sangat menekankan kepada umatnya untuk melakukan kegiatan komunikasi Islam meskipun hal yang disampaikan itu hanya satu ayat al-Quran saja.

\section{B. Perubahan sosial.}

Perubahan sosial adalah proses sosial yang dialami oleh anggota masyarakat serta semua unsur-unsur budaya dan sistem-sistem sosial, dimana semua tingkat kehidupan masyarakat secara sukarela atau dipengaruhi oleh unsur-unsur eksternal meninggalkan pola-pola kehidupan, budaya, dan sistem sosial lama kemudian menyesuaikan diri atau menggunakan pola-pola kehidupan, budaya, dan sistem sosial yang baru.

117 Departemen Agama RI, Al-Hikmah, Al-Quran dan Teriemahnya (Cet. X; Bandung: CV. Penerbit Diponegoro, 2008), 281 
Perubahan sosial terjadi ketika ada kesediaan anggota masyarakat untuk meninggalkan unsur-unsur budaya dan sistem sosial lama dan mulai beralih menggunakan unsur-unsur budaya dan sistem sosial yang baru. Perubahan sosial dipandang sebagai konsep yang serba mencakup seluruh kehidupan masyarakat baik pada tingkat individual, kelompok, masyarakat, dan dunia yang mengalami perubahan. ${ }^{118}$

Hal-hal penting dalam perubahan sosial menyangkut unsur-unsur sebagai berikut, yaitu;

\section{Perubahan Pola Pikir Masyarakat}

Perubahan pola pikir masyarakat dan sikap masyarakat menyangkut persoalan sikap masyarakat terhadap berbagai persoalan sosial dan budaya di sekitarnya yang berakibat terhadap pemetaraan pola-pola pikir baru yang dianut oleh masyarakat sebagai sebuah sikap yang modern. Contohnya, sikap terbadap pekerjaan bahwa konsep dan pola pikir lama tentang pekerjaan adalah sektor formal yaitu menjadi pegawai negeri, sehingga konsep pekerjaan dibagi menjadi dua, yaitu sektor formal dan informal.

Saat ini terjadi perubahan terhadap konsep kerja, dimana bekerja tidak saja di sektor formal atau menjadi pegawai negeri sipil saja, akan tetapi di mana saja yang penting menghasilkan vang yang baik, halal dan berkah dapat dikatakan seseorang telah bekerja, seperti; bekerja sebagai wiraswasta, pedagang kaki lima, home industry (bisnis rumahan), bekerja di Lembaga Swadaya Masyarakat

\footnotetext{
118 M. Burhan Bungin, Sosiologi Komunikosi, Teori Paradigma, dan Diskursus Teknologi Komunikasi di Masyarakat (Cet. II; Jakarta: Kencana Prenada Media Group, 2007), 91
} 
(LSM), bekeria di sektor pabrik, perusahaan swasta, perbankan atan sebagai karyawan di swalayan maupun mini market dan lain sebagainya.

Terjadinya perubahan pola pikir masyarakat dan sikap mereka terhadap problem sosial dan budaya di sekitarnya tidak terlepas dari pengaruh kegiatan komunikasi Islam yang banyak dilakukan oleh para praktisi kegiatan tersebut.

\section{Perubahan Perilaku Masyarakat}

Perubahan perilaku masyarakat menyangkut persoalan perubahan sistemsistem sosial, dimana masyarakat meninggalkan sistem sosial lama dan menjalankan sistem sosial baru, seperti; perubahan perilaku pengukuran kinerja suatu lembaga atau instansi. apabila pada sistem lama, ukuran-ukuran kinerja hanya dilihat dari aspek output dan proses tanpa harus mengukur sampai dimana out put dan proses itu dicapai, maka pada sistem sosial yang baru sebuah lembaga atau instansi diukur sampai pada tingkat kinerja out put dan proses, yaitu dengan menggunakan standar sertifikasi seperti BAN-PT (Badan Akreditasi Nasional Perguruan Tinggi) pada Perguruan Tinggi dan sertifikasi ISO pada lembaga lembaga umum termasuk Perguruan Tinggi.

\section{Perubahan Budaya Materi}

Perubahan budaya Materi menyangkut perubahan artefak budaya yang digunakan oleh masyarakat seperti model pakaian, karya fotografi, karya film, teknologi, dan sebagainya yang terus berubah dari waktu ke waktu menyesuaikan kebutuhan masyarakat. ${ }^{119}$

\footnotetext{
${ }^{119} \mathrm{M}$. Burhan Bungin, Sosiologi Komunikasi, Teori, Paradigma, dan Diskursus Teknologi Komunikasi di Masyarakat, 92
} 
Berikut ini penulis akan memaparkan tahapan transisi sosiologis, yang berawal dari masyarakat primitif, masyarakat agrokultural, masyarakat tradisional, masyarakat transisi, masyarakat modern dan masyarakat postmodern.

Masyarakat memulai kehidupan mereka pada suatu fase yang disebut primitif dimana manusia hidup secara terisolir dan berpindah-pindah disesuaikan dengan lingkungan alam dan sumber makanan yang tersedia.

Masyarakat sering diorganisasikan berdasarkan cara utamanya dalam bermata pencaharian. Pakar ilmu sosial mengidentifikasikan ada: masyarakat pemburu, masyarakat pastoral nomadis, masyarakat bercocoktanam, dan masyarakat agrikultural intensif, yang juga disebut masyarakat peradaban.

Masyarakat industri dan pasca-industri sebagai kelompok masyarakat yang terpisah dan masyarakat agrikultural tradisional. Dalam masyarakat tradisional seluruh hidup seseorang menjadi penuh makna yang jelas. Umumnya agamalah yang telah mengartikan dan menilai semua bidang dan tahap kehidupan sesuai dengan kebutuhan masing-masing. Agamalah yang merumuskan identitas tiaptiap orang, semua kejadian dalam hidup dan semua gejala alam di luar ditafsirkan dan diterangkan oleh agama, mulai dan lahir sampai saat ajal seseorang tiba, didampingi, dibimbing dan dibantu oleh agama, sehingga hidup yang penuh rahasia tidak membingungkan atau menggelisahkan orang, melainkan menjadi sumber ketentraman dan damai. Sedangkan dalam masyarakat modern termasuk dalam masyarakat industri bukan agama 
melainkan ilmu pengetahuan yang rnenerangkan arti hidup manusia. ${ }^{120}$ Masyarakat dapat pula diorganisasikan berdasarkan struktur politiknya: berdasarkan urutan kompleksitas dan besar, terdapat masyarakat band, suku, chiefdom, dan masyarakat negara.

Menurut Straubhaar dan La Rose (2004), Masyarakat Industri mengacu pada teriadinya Revolusi Industri, yang umumnya dikaitkan dengan penemuan mesin vap. Namun sesungguhnya, pemicu penting menuju era industri tersebut dimulai dengan penemuan di bidang komunikasi, yakni publikasi Bible yang diproduksi dengan mesin cetak pengembangan dan Johannes Guttenberg (1455). Mesin cetak ini merupakan yang pertama kalinya di Eropa yang menggunakan cetak logam yang dapat digerakkan (movable metal type). Penemuan ini secara dramatis meningkatkan kecepatan produksi buku dan mengurangi waktu yang digunakan seperti pada produksi buku sebelumnya (hand-copied book). Jenis hand-copied book ini lama-kelamaan digantikan dengan buku cetakan dengan harga lebih murah dan bersifat massal. Target pembacanya juga makin meluas seiring dengan makin beragamnya jenis buku yang ditulis dan ditawarkan.

Masyarakat (sebagai terjemahan istilah society) adalah sekelompok orang yang membentuk sebuah sistem semi tertutup (atau semi terbuka), dimana sebagian besar interaksi adalah antara individu-individu yang berada dalam kelompok tersebut. Masyarakat berarti kumpulan individu yang menjalin kehidupan bersama sebagai satu kesatuan yang besar yang saling membutuhkan,

\footnotetext{
${ }^{120}$ K.J. Veeger, Realitas Sosial (Cet. II; Jakarta: PT. Gramedia, 1986), 190
} 
memiliki ciri-ciri yang sama sebagai kelompok. ${ }^{121}$ Abstraknya, sebuah masyarakat adalah suatu jaringan hubungan-hubungan antar entitas-entitas, dan umumnya, istilah masyarakat digunakan untuk mengacu pada sekelompok orang yang hidup bersama dalam satu komunitas yang teratur.

Masyarakat sebagai kelompok dapat digolongkan dalam beberapa kategori yaitu; Masyarakat Agraris, Masyarakat Industri dan Masyarakat Informasi. Perbedaan Masyarakat Agraris, Masyarakat Industri, dan Masyarakat Informasi adalah sebagai berikut; Masyarakat agraris, sumber daya yang diolah adalah Sumber daya alam yaitu; Angin, air, tanah dan manusia. Masyarakat industri, membuat tenaga (listrik, bahan bakar). Masyarakat informasi, sumber daya yang diolah adalah Informasi (transmisi data dan komputer). ${ }^{122}$ Masyarakat agraris, sumber daya yang dibutuhkan adalah bahan mentah atau alam. Masyarakat industri sumber daya yang dibutuhkan adalah modal, sedangkan dalam masyarakat informasi yaitu pengetahuan. ${ }^{123}$

Dari segi keahlian SDM (sumber daya manusia) yang dibutuhkan: Masyarakat agraris; Petani, pekerja tanpa skill tertentu. Masyarakat industri; Ahli mesin, pekerja dengan skill khusus. Masyarakat informasi; Pekerja profesional

\footnotetext{
${ }^{121}$ Badudu-Zain, Kamus Umum Bahasa Indonesia (Cet. IV; Jakarta: Pustaka Sinar Harapan, 2001), 872.

122 Soerjono Soekanto, Sosiologi Suatu Pengantar (Jakarta: PT RajaGrafrndo Persada, 2007), 36-37.

${ }^{123}$ John Scott, Teori Sosial Masalah-Masalah Pokok dalam Sosiologi (Yogyakarta: Pustka Pelajar, 2012), 327.
} 
(dengan skill tinggi). ${ }^{124}$ Adapun teknologi yang digunakan dalam masyarakat agraris yaitu; Alat-alat manual. Pada masyarakat industri yaitu; Teknologi mesin. Dan pada masyarakat informasi adalah Teknologi cerdas. ${ }^{125}$ Prinsip perkembangan dalam masyarakat agraris: Tradisional. Dalam masyarakat industri; Pertumbuhan ekonomi. Dan dalam masyarakat informasi: Penerapan pengetahuan dalam teknologi. Berdasarkan Model produksi dalam bidang ekonomi: Masyarakat agraris yaitu; Pertanian, pertambangan, perikanan," peternakan. Masyarakat industri yaitu; Produksi, distribusi barang; konstruksi berat. Sedangkan dalam Masyarakat informasi yaitu; Transportasi, perdagangan, asuransi, real estate, kesehatan, rekreasi, penelitian, pendidikan, pemerintahan. $^{126}$

Perkembangan peradaban manusia terasa begitu cepatnya, kita tentunya mengenal masyarakat primitif, pada era itu seseorang untuk mendapatkan suatu barang harus ditukar dengan barang lagi (barter), kemudian meningkat ke masyarakat agraris, kemudian masyarakat industri. Dan masyarakat indusri loncat ke masyarakat informasi (era informasi). Mengapa dikatakan loncat ke masyarakat informasi? karena kita baru memulai melangkah ke masyarakat industri, era informasi sudah datang. Dengan era informasi ini, semuanya menjadi serba; yaitu serba mudah, serba murah, serba cepat, tepat, dan akurat.

124 Soerjono Soekanto, Buck Sulistyowti, Sosiologi suatu Pengantar (Jakarta: RajaGrafindo Persada, 2014), 137. Mei 2015).

${ }^{125} \mathrm{http}: /$ Istudents.ukdw. ac.id/. 22033132/komputer\%20masyarakat/perbedaan.html, (20

${ }^{126}$ Alo Liliweri, Pengantar Studi Kebudayaan (Cet.l; Bandung: Nusa Media, 20 M), 438. 
Namun disamping itu ada sisi negatifnya, sebagai contoh dengan era informasi ini seorang auditor dapat melakukan supervisi audit di tempat yang berbeda, melakukan transaksi bisnis melalui internet (e-commerce). Hal ini bisa juga menyerap informasi budaya yang jelek, yang dapat merubah perilaku dan etika seseorang. Oleh karena itu diperlukan sikap arif dalam menyikapi era informasi ini, kita tidak boleh terjebak perdebatan dampak positif dan negatifnya era ini, tetapi yang harus kita bangun adalah kemauan untuk merubah diri dan membangun komunikasi Islam yang baik dan terarah termasuk di dalamnya komunikasi di cyber space (dunia maya).

Manusia cenderung bersifat dinamis. Selalu ada perubahan yang terjadi pada diri manusia. Semakin meningkatnya kebutuhan hidup sementara sumber daya alam yang tersedia semakin menipis dan lahan kerja yang tidak memadai, keterbatasan lahan perkotaan untuk migrasi, pemerataan pembangunan dan penghematan biaya produksi menyebabkan munculnya keinginan untuk menciptakan satu hal baru yang dapat meningkatkan taraf hidup menjadi lebih baik dengan mengubah pola hidupnya. Perubahan paling sederhana yang tampak adalah alih fungsi lahan pertanian menjadi kawasan industri dan kawasan perumahan yang tentu berdampak pada beralihnya profesi masyarakat petani ke profesi lain. Hal ini mempunyai pengaruh pada pola hidup, mata pencaharian, perilaku maupun cara berpikir.

Masyarakat dan kebudayaan memang saling mempengaruhi, baik secara langsung maupun tidak langsung. Pengaruh tersebut dimungkinkan karena kebudayaan merupakan produk dari masyarakat. Pengaruh yang nantinya akan 
membuat perubahan umumnya terjadi karena adanya tuntutan situasi sekitar yang berkembang. Sehingga, masyarakat yang awalnya masyarakat pertanian lambat laun berubah menjadi masyarakat industri, masyarakat modern dan masyarakat informasi.

Menurut hemat penulis ada beberapa ciri khusus sebagai contoh masyarakat industri yang perlu diperhatikan untuk pemecahan masalah bagi umat Islam, diantaranya ialah:

Pertama, mereka dalam menyambung kehidupan tidak melewati lahan pertanian seperti masyarakat agraris atau mengandalkan hasil peternakan, seperti masyarakat padang pasir, melainkan pada jalannya mesin-mesin pabrik, khususnya di daerah perkotaan, sedangkan pertanian dikerjakan di daerah pedesaan dalam lokalisasi yang sangat kecil.

Ketergantungan masyarakat industri terhadap pabrik, sama halnya bergantung dengan penguasa pabrik, tidak jarang dijumpai penguasa pabrik bersikap tidak etis atau tidak manusiawi terhadap pekerja diantaranya melarang beribadah, membuka aurat, memaksa ikut upacara agamanya, bila tidak bersedia akan dikeluarkan. Mereka yang tidak tahan menghadapi kesulitan hidup mudah melepaskan kepercayaan agamanya. Berbeda dengan masyarakat yang menggantungkan hidupnya dengan tanah pertanian, tanah tersebut tidak mampu memaksakan orang berlaku dholim.

Kedua, Potensi-potensi kehidupan terdapat pada sarana-sarana yang dapat menunjang perkembangan pabrik diantaranya ialah ilmu pengetahuan yang berhubungan dengan gedung misalnya pengetahuan arsitek atau sipil, yang 
berhubungan dengan pengaturan personalnya terdapat pada pengetahuan personalia atau manajemen untuk pengembangan produksi terdapat pada manajemen pemasaran, akuntansi untuk kegiatan administrasinya dan masih banyak lagi pengetahuan untuk bekal hidup pada Masyarakat Industri.

Pengetahuan yang tidak berhubungan langsung untuk menunjang produksi kurang mendapatkan perhatian, misalkan pengetahuan keguruan, lebih dijauhkan lagi apabila bidangnya tidak berhubungan dengan produksi, misalkan bidang keagamaan, sejarah, bahasa, atau filsafat. Secara alamiah akan terjadi kelas ilmu pengetahuan, pengetahuan teknik perusahaan lebih dominan daripada pengetahuan sosial. Akibatnya mereka akan cepat mendapatkan kemajuan material akan tetapi sangat ketinggalan terhadap permasalahan nilainilai kemanusiaan, kehidupan dan ketuhanan.

Ketiga, Kecintaan masyarakat industri terhadap kebahagiaan material sangat besar dibandingkan dengan kebahagiaan immaterial, sebagaimana kebahagiaan masyarakat agraris, yang lebih menekankan pada kerukunan, kasih sayang dan saling menghormati. Hal itu dapat dimaklumi karena bentuk-bentuk kebahagiaan material pada masyarakat industri kuantitas dan kualitasnya sangat banyak, variatif dan selalu mengalami perubahan, berkat dukungan kemajuan pengetahuan teknologi. Mereka lebih baik mengorbankan kebahagiaan immaterial yang ruang lingkupnya lebih kecil, demi kebahagiaan material. Sehingga masyarakat industri banyak mengalami gangguan psikis, rasa ketegangan, persaingan, ketakutan terhadap ketertinggalan dan konflik, 
perjudian, wanita dan minuman keras sering dijadikan tempat hiburan untuk menghilangkan ketegangan. ${ }^{127}$

Dari sekian persoalan yang dialami oleh masyarakat industri sebagai bentuk perubahan sosial, perlu disikapi dengan bijak dan direspon dengan baik. Salah satu di antara realitas sosial dalam membangun solusi terhadap persoalan tersebut adalah dengan melakukan kegiatan komunikasi Islam, dimana terjadinya proses komunikasi di dalam kehidupan masyarakat disertai dengan nilai-nilai ajaran Islam.

Adapun perilaku negatif terhadap perubahan sosial sebagai berikut:

a. Penyalahgunaan Teknologi

Teknologi di sisi lain dapat memudahkan dan membantu kehidupan manusia jika digunakan secara bijaksana. Akan tetapi ketika teknologi digunakan secara tidak bijaksana, dapat menimbulkan dampak negatif. Misalnya saja teknologi internet digunakan oleh sebagian orang untuk pornografi dan melakukan kejahatan di dunia maya.

b. Perilaku Kebarat-Baratan

Westernisasi adalah suatu asimilasi kebudayaan Barat atau proses sosial yang memperkenalkan kebiasaan dan praktik-praktik peradaban Barat. Hal ini terjadi karena mereka menganggap semua yang dari Barat modern. Mereka bertingkah seperti orang Barat agar dianggap modern. Buktinya yaitu gaya hidup mereka yang ala Barat, mulai dari cara berpakaian hingga pola

\footnotetext{
${ }^{127}$ http://students.ukdw.ac.id/22033132/komputer\%20masyarakat/perbedaan.html. (diakses pada tanggal 21 Mei 2016).
} 
makan. Bila diamati, budaya Barat berpotensi mengubah cara berpikir, cara bekerja, dan cara hidup kita. Ketiga aspek ini tak semuanya negatif atau positif. Dari ketiga aspek itu, cara hidup lebih cepat berubah dari pada cara berpikir ataupun cara bekerja. Tanpa sadar masyarakat membiarkan kebudayaan Barat mengubah pola hidup mereka. Gaya hidup masyarakat yang khas sudah mulai menghilang.

c. Konsumerisme

Konsumerisme merupakan sikap atau perilaku suka membeli barang untuk mendapatkan prestise atau gengsi tertentu, tanpa memperhatikan kegunaanya. Perilaku seperti ini lebih mendahulukan pemenuhan keinginan dengan gaya hidup mewah daripada pemenuhan kebutuhan pokok.

\section{Komunikasi Islam dan Perubahan Sosial.}

Komunikasi Islam sekarang harus mengarah pada penanganan masalah riil. Artinya bahwa kegiatan komunikasi Islam harus merupakan usaha pemecahan atau penyelesaian masalah kehidupan umat dan masyarakat di bidang sosial-budaya, ekonomi dan politik dalam kerangka masyarakat modern. Adapun bentuk komunikasi Islam yang dapat dilakukan bisa secara formal dalam kegiatan individu di lingkungan akademisi, lembaga pendidikan sosial maupun lembaga dakwah, dan bisa juga secara non formal yang dilakukan oleh individu dalam kehidupan sosial masyarakat.

Dengan memahami komunikasi Islam sebagai pemecahan masalah diharapkan membuahkan tiga kondisi: pertama, tumbuhnya kemandirian dan 
kepercayaan umat serta masyarakat sehingga berkembang sikap optimis. Kedua, tumbuhnya kepercayaan terhadap kegiatan komunikasi Islam guna mencapai tujuan hidup yang lebih ideal berdasarkan nilai-nilai ajaran Islam. Ketiga, berkembangnya suatu kondisi sosial dan ekonomi, politik serta iptek sebagai landasan peningkatan kualitas hidup umat.

Uraian di atas, setidaknya memberi kita jalan untuk memperlebar makna komunikasi Islam secara lebih efektif. Dalam arti yang paling sempit komunikasi Islam adalah melakukan kegiatan komunikasi dalam bentuk memanggil dan mengajak seseorang atau sekelompok orang untuk mengamalkan ajaran agama Islam. Sedangkan arti yeng lebih luas komunikasi Islam bisa dipahami sebagai upaya peningkatan kualitas sumber daya manusia, pengentasan kemiskinan, memerangi kebodohan dan keterbelakangan, serta meningkatkan kesejahteraan sosial.

Dalam melakukan aktivitas komunikasi Islam, diharapkan umat Islam menggunakan berbagai macam media yang dirasa lebih efektif untuk digunakan. Misalnya, melalui media klasik dalam kegiatan ceramah-ceramah keagamaan, seni, atau pun melalui tulisan-tulisan yang berisikan tentang ajaran-ajaran Islam yang berasal dari al-Quran dan Hadis sebagai materi utamanya dalam berbagai bentuk tulisan kaligrafi Arab.

Pemilihan media dalam melakukan kegiatan komunikasi Islam harus mempertimbangkan pada segmentasi komunikan ( $\operatorname{mad}^{\prime} u$ ), karena satu media bisa menjadi efektif untuk satu komunitas tertentu namun bisa juga menjadi tidak efektif untuk komunitas yang lain. Seiring dengan perkembangan zaman dan 
perkembangan yang terjadi dalam tingkat pendidikan masyarakat, maka metode komunikasi Islam pun harus mengikuti tingkatan perkembangannya.

Komunikasi Islam harus dikemas sedemikian rupa agar terlihat lebih menarik, tidak hanya berupa kegiatan komunikasi pada umumnya dalam kehidupan interaksi sosial, tetapi komunikasi Islam dapat dilakukan dan disampaikan melalui lagu-lagu religi, qasidah, puisi, dan lain sebagainya.

Komunikasi Islam dapat juga dilakukan dalam bentuk tulisan maupun verbal yang ditampilkan dalam berbagai macam media elektronik, media cetak ataupun melalui media internet. Saat ini penggunaan sarana dalam melakukan kegiatan komunikasi Islam banyak sekali, sebut saja melalui media internet dengan berbagai fasilitas yang tersedia di dalamnya, seperti; youtube, facebook, yang begitu mudahnya dapat diakses oleh banyak orang, tidak hanya melalui laptop atau notebook, tapi juga bisa diakses melalui handphone (HP), serta beberapa pilihan aplikasi lainnya yang tersedia di dalam kecanggihan teknologi komunikasi, seperti; BBM, WhatsApp, Wechat, Line dan aplikasi lainnya yang bisa digunakan sebagai sarana untuk menunjang efektifitas proses kegiatan komunikasi Islam. Adapun beberapa faktor yang mendukung efektifitas keberhasilan komunikasi Islam dalam perubahan sosial yaitu;

a. Pemahaman yang rinci, yakni penyampaian komunikasi Islam tidak boleh ada materi yang disembunyikan atau dirahasiakan, tapi harus disampaikan apa adanya berdasarkan al-Quran dan Hadis.

b. Keimanan yang mendalam, kekuatan tauhid atau keimanan yang mendalam akan menjadi dasar penguat yang sulit untuk dipengaruhi. 
c. Kecintaan yang kokoh, rasa cinta yang mendalam terhadap ajaran Rasulullah saw melahirkan kekuatan yang solid dalam akidah dan pengamalan ajaran Islam.

d. Kesadaran yang sempurna tentang pentingnya komunikasi Islam sehingga melahirkan rasa tanggungjawab atas kewajiban dalam melakukan kegiatan komunikasi Islam, serta dilakukan secara konsisten. ${ }^{128}$

Komunikasi Islam dalam perubahan sosial tentunya banyak tantangan dan hambatan yang harus dilalui dan diurai secara holistik, dengan mencari dan menemukan alternatif solutif bagi efektivitas dan ketepatan komunikasi Islam kontemporer. Di antara permasalahan konkrit pada perilaku perubahan sosial, penulis dapat kemukakan beberapa perilaku kehidupan sosial yang jauh mengalami perubahan dibandingkan pada masa kehidupan masyarakat agraris, yaitu;

1. Masyarakat modern saat ini lebih banyak meninggalkan nilai-nilai tradisional.

2. Lebih kompetitif dalam meningkatkan produktifitas kerja dan kemapanan sosial.

3. Hidup lebih berkelas, dan sering menjaga prestice (gengsi).

4. Lebih mencintai kesenangan material dari pada kebahagiaan immaterial.

5. Hedonism, berfoya-foya dan memperturutkan hawa nafsu. 106.

${ }^{128}$ Sampo Seha, Paradigma Dakwah: Menata Ulang Penerapan Dakwah di Indonesia, $105-$ 


\section{Kesimpulan}

Sebagai penutup dari uraian di atas dapat disimpulkan bahwa: Perubahan sosial adalah proses sosial yang dialami oleh anggota masyarakat serta semua unsur-unsur budaya dan sistem-sistem sosial, dimana semua tingkat kehidupan masyarakat secara sukarela atau dipengaruhi oleh unsur unsur eksternal meninggalkan pola-pola kehidupan, budaya, dan sistem sosial lama kemudian menyesuaikan diri atau menggunakan pola-pola kehidupan, budaya, dan sistem sosial yang baru. Komunikasi Islam dalam perubahan sosial harus mengarah pada penanganan masalah riil. Artinya bahwa kegiatan komunikasi Islam harus merupakan usaha pemecahan atau penyelesaian masalah kehidupan umat dan masyarakat di bidang sosial-budaya, ekonomi dan politik dalam kerangka masyarakat modern. Dengan memahami komunikasi Islam sebagai pemecahan masalah dapat membuahkan tiga kondisi: pertama, tumbuhnya kemandirian dan kepercayaan umat serta masyarakat sehingga berkembang sikap optimis. Kedua, tumbuhnya kepercayaan terhadap kegiatan komunikasi Islam guna mencapai tujuan hidup yang lebih ideal. Ketiga, berkembangnya suatu kondisi sosial dan ekonomi, politik serta iptek sebagai landasan peningkatan kualitas hidup umat. 


\section{Daftar Pustaka}

Badudu-Zain, Kamus Bahasa Indonesia. Cet. IV; Jakarta: Pustaka Sinar Harapan, 2001.

Bungin, H.M. Burhan, Sosiologi Komunikasi, Teori, Paradigma, dan Diskursus Teknologi Komunikasi di Masyarkat. Cet. II, Jakarta,: Kencana Prenada Media Group, 2017.

Departemen Agama RI, Al-Hikmah, AL-Quran dan Terjemahannya. Cet. X, Bandung: CV. Penerbit Diponegoro, 2008.

Hefni, Herjani, Komunikasi Islam. Cet. L: Jakarta: Prenada Media Group, 2015.

K.J. Veeger, Realitas Sosial. Cet. II. Jakarta: PT. Gramedia, 1986.

Liliweri, Alo, Pengantar Studi Kebudayaan. Cet. I: Bandung Nusa Media, 2014.

Roland Robertson, ed, Sociology of Religion, edisi terjemahan Agama dalam Analisa dan Interpretasi Sosiologi. Cet I; Jakarta; Rajawali Pers, 1988.

Philip K. Hitti, History of Arabs, from the earliest times to the Present. Cet. X; London: The Macmilan Press Ltd, 1974.

Scott, John, Teori Sosial Maslah-masalah Pokok dalam Sosiologi. Yogyakarta: Pustaka Pelajar, 2012.

Soekanto, Soerjono, Sosiologi Suatu Pengantar. Jakarta: PT. Raja Grafindo Persada, 2007.

Soekanto, Soerjono, Budi Sulistyowati, Sosiologi Suatu Pengantar. Jakarta: Raja Grafindo Persada, 2014.

Http://students.ukdw.ac.id/ 22033132/komputer\%masyarakat/perbedan.html, (20 Mei 2016).

Http://students.ukdw.ac.id/ 22033132/komputer\%masyarakat/perbedan.html, Mei 2016) 